\title{
Food Itineraries in the Context of Crisis in Catalonia (Spain): Intersections between Precarization, Food Insecurity and Gender
}

\author{
Mabel Gracia-Arnaiz $^{1}$ (D), Montserrat Garcia-Oliva ${ }^{2}(\mathbb{D})$ and Mireia Campanera $^{1, *(\mathbb{D})}$ \\ 1 Departament Antropologia, Filosofia i Treball Social, Facultat de Lletres, Universitat Rovira i Virgili, \\ 43002 Tarragona, Spain; mabel.gracia@urv.cat \\ 2 Pere Tarrés Faculty of Social Education and Social Work, Universitat Ramon Llull, 08022 Barcelona, Spain; \\ mgarcia2@peretarres.org \\ * Correspondence: mireia.campanera@urv.cat
}

check for

updates

Citation: Gracia-Arnaiz, Mabel, Montserrat Garcia-Oliva, and Mireia Campanera. 2021. Food Itineraries in the Context of Crisis in Catalonia (Spain): Intersections between Precarization, Food Insecurity and Gender. Social Sciences 10: 352. https://doi.org/10.3390/socsci 10100352

Academic Editor: Jean Pierre Poulain

Received: 27 July 2021

Accepted: 14 September 2021

Published: 23 September 2021

Publisher's Note: MDPI stays neutral with regard to jurisdictional claims in published maps and institutional affiliations.

Copyright: (c) 2021 by the authors. Licensee MDPI, Basel, Switzerland. This article is an open access article distributed under the terms and conditions of the Creative Commons Attribution (CC BY) license (https:// creativecommons.org/licenses/by/ $4.0 /)$.

\begin{abstract}
This work analyzes the relationship between the precarization of everyday life and the increase in food insecurity in Catalonia (Spain). Based on an ethnographic analysis of the food itineraries of a group of people in a situation of precarity, this article examines their lived experiences under the pressure of having to meet daily food needs. The results show that gender differences are significant in terms of the strategies adopted, particularly in the forms of acquisition and preparation, places of consumption and support networks. Given that women are largely responsible for feeding the household, they are the ones most often managing the attendant difficulties. In situations where access to food depends on diverse and irregular sources, they engage in practices that both protect the family group's basic need to eat and sometimes compromise their own health, eating less than is usual and/or sufficient, skipping meals or even, on occasion, going hungry. The study concludes that providing food involves a crucial set of knowledge and skills for social reproduction that is not incorporated into existing emergency programs, with specific actions to avoid gender inequality likewise being omitted. The article proposes that both issues be discussed and taken into account in health and social policy. This study analyzes a subject that has scarcely been addressed in Spain. The challenge in investigating food insecurity from a gender approach is not only to make visible the crucial roles of women in food security and their contribution to it but also to show how the process of precarization manifests itself unequally across households.
\end{abstract}

Keywords: crisis; poverty; food insecurity; social inequality; food assistance

\section{Introduction}

The socio-anthropological literature shows that, although the field of cooking can be extremely conservative in some aspects-particularly in relation to edibility and culinary grammar-this does not preclude relevant modifications if the context changes (Fischler 1995). After all, ruptures and continuities are common features in any process of social change (Mennell 1985). While the right to food is barely achieved for millions of people in the world's poorest countries (Messer 2009), international political and economic events in the last two decades have also called that right into question in industrialized societies. Global in extent, the great recession that began in 2008 has had negative consequences right up to the present day, compounded by issues driven by the COVID-19 pandemic. These consequences have meant, among other things, an increasing precarization that has translated into food insecurity. Thus, the political measures adopted from 2008 to 2020 in some European countries, and particularly in Spain, such as cuts to social and health assistance, labor reforms, or temporary and low-paid jobs, have contributed to the transformation, to a greater or lesser degree, of the repertoire of affordable foods, the ways in which they are prepared and consumed, and the reasons why people in a vulnerable situation choose one way or another. 
According to Bramall (2013), this new "age of austerity", which has repeatedly been compared to the Second World War or the Spanish Civil War in its consequences for the everyday life of people, turns out to be full of limitations and contradictions. Precarization is a more open conceptual field than the scope afforded to the terms "precarious" or "precarity" by 1980s social science literature, with regard to the difficulties caused mainly by the flexibilization of the labor market and the worsening of employment conditions. This is a ubiquitous and multidimensional process that affects all sectors. Lorey (2015) proposes the term "governmental precarization", in contradistinction to the Hobbesian idea of a State that provides security, pointing out that in neoliberal governments, where precarization is undergoing a process of normalization, it is precisely through insecurity that they rule, whether that is economic, occupational, social or general life insecurity, which is applicable both to the generalized precarity of living conditions and to the social and political responses generated to tackle such uncertainties. This is consistent with the concept of precarization as described by Paugam (2013), which reflects a dynamic idea about what is considered a process in terms of socio-economic instability. It is not necessary to be in extreme poverty to experience precariousness. The term not only refers to a financial indicator, but also to changes in the terms of restrictions on consumption, difficulties paying housing costs, the mortgage, electricity and gas bills, or buying food.

As in other countries (Lambie-Mumford 2017; Borch and Kjaernes 2016), the growing precarization in Spain has highlighted the effects of inequalities in the mechanisms of access, distribution, and consumption of food. It is doubtful that there is a single way of conceiving and diagnosing situations that entail difficulties in eating regularly and, therefore, one single approach to experiencing and/or dealing with food insecurity (McIntosh 1996); here, we understand it as a consequence of the growth in poverty. Rather than being simply a condition caused by insufficient economic means for purchasing food to meet adequate caloric intake, the experience of food insecurity is multidimensional and is shaped by the complex interaction of multiple political, economic, and social factors (Pottier 1999). The problem exists when there are structural limitations and is both flexible and changeable in nature. It does not appear in isolation, as low-income families or subjects are affected by multiple, overlapping issues, like lack of affordable housing, social isolation, chronic or acute health problems, high medical costs, or gender discrimination (Russomanno and Tree 2020; Hernandez et al. 2017; Ma et al. 2021). In this study, we employ a notion of food insecurity that reflects not only a greater or lesser degree of food deprivation or even hunger but also people's capacity to face and respond to the difficulties arising, as well as the measures that each society establishes (or does not establish) for their care and protection.

Despite problems with availability or the supply of markets and shops going unrecorded, successive restrictions have eroded one of the most basic human rights in this country. According to the AROPE index (At risk of poverty or social exclusion, AROPE), the proportion of the population at risk of social exclusion rose from $23.3 \%$ in 2007 to $29.2 \%$ in 2014; although in 2020, this figure will be around 26.4\% (INE, Instituto Nacional de Estadística ${ }^{1}$ ), there are still more impoverished people than before the great recession. In Catalonia, this risk rate is $26.3 \%$, with $6.2 \%$ of the population in severe deprivation ${ }^{2}$. This poverty has been accompanied by a growing difficulty in meeting basic needs, among them regular access to adequate, healthy, and culturally acceptable foods. According to the latest Food and Agriculture Organization (FAO) reports (FAO et al. 2019, 2020), the number of Spaniards in a situation of food insecurity has gone from 600,000 to 700,000 in just one year. The state has responded to the growing demand for assistance mainly by relying on non-profit organizations that provide food pantries and run catering services. Although no official data is available, third-sector reports and socio-anthropological studies indicate that the people who have experienced greater forms of food insecurity are women (Llobet et al. 2020), as they have had to mobilize their own and/or other people's resources in order to minimize the impact of precarization on their households. Although few studies have paid specific attention to these women's own food security circumstances, the situation 
in Spain is similar to that in other industrialized countries (Broussard 2019). Differences occur because women tend to have fewer monetary resources than men and because, even though they are responsible for food, the pattern of food distribution among family members often undermines their well-being and health.

This article analyzes the relationship between precarization, food insecurity and gender in Catalonia, an autonomous community located in the northeast of Spain, over the last decade. The working hypothesis is that while precarization generates an uncertainty that limits the quality of life because it requires a constant change of tactics, it also promotes responses that can act as alternative pathways to those options that have typically been offered by social services. The results show, on the one hand, that people manage the daily business of providing food by adopting a variety of strategies and negotiating with a range of interlocutors, groups and institutions in different contexts. On the other hand, the findings confirm that gender differences are significant in terms of the strategies adopted, particularly in the forms of acquisition and preparation, places of consumption, and support networks. Given that women are largely responsible for feeding their household, they are the ones most often managing the attendant difficulties. Their food itineraries express both the dynamic and changing nature of precarization, and the importance that that support assumes in the management of deprivation. The activation of several social networks (family, civil organizations, neighborhood associations) is essential for understanding why hunger has not affected many people living in vulnerable situations. The study concludes that providing food involves a crucial set of knowledge and skills for social reproduction that are not incorporated into existing emergency programs, with specific actions to avoid gender inequality being likewise omitted. The authors propose that both issues be discussed and taken into account in health and social policy.

\section{Materials and Methods}

This work forms part of a broader study (The precarization of everyday life: food (in)security, gender and health" (Ministry of Science and Innovation, reference CSO201674941-P, 2016-2019) that continues today with the Research \& Development Project (Eating matters: precarization and (in)secure food itineraries in older people" (Ministry of Science and Innovation, reference PID2019-104253RB-C21). Carrying this out involved drawing on various sources of information which, in the wake of the 2008 crisis, enabled analysis of the food itineraries of people in precarious situations. First, an existing literature review was updated to identify the socioeconomic dimensions of the crisis (Gracia-Arnaiz 2019), by searching the SCOPUS database for studies published between 2008 and 2019 that examined the negative consequences of unemployment and cuts to wages and social services. We also selected studies on Spanish social policy, dealing with growing impoverishment and food insecurity. The studies chosen were those published in Spanish or English and based on populations in Spain, as well as comparative studies extending to other European countries. The search terms included: economic crisis, poverty, gender, food consumption, benefit cuts, food security and social policies (see Figure 1). This search yielded 13,680 sources. After applying inclusion criteria (publication dates, type of publication, language, location of study and subject matter), a total of 621 publications were identified. Of these 621 journal articles and book chapters, 220 were eventually selected for their relevance to the study aims.

Second, in order to analyze the social measures adopted to meet basic needs and acquire food, we compiled the main action plans, specifically those anti-poverty and food assistance programs implemented by Spanish government agencies and third-sector organizations at municipal, regional and state levels, with a focus on documents published between 2008 and 2019. These include the Ministry of Health, Social Services and Equality, FEAD (the European Fund to Aid the Most Deprived, 2014-2020), FESBAL (the Spanish Federation of Food Banks), the Red Cross and Caritas. A total of 25 out of the initial selection of 37 documents met the inclusion criteria. 


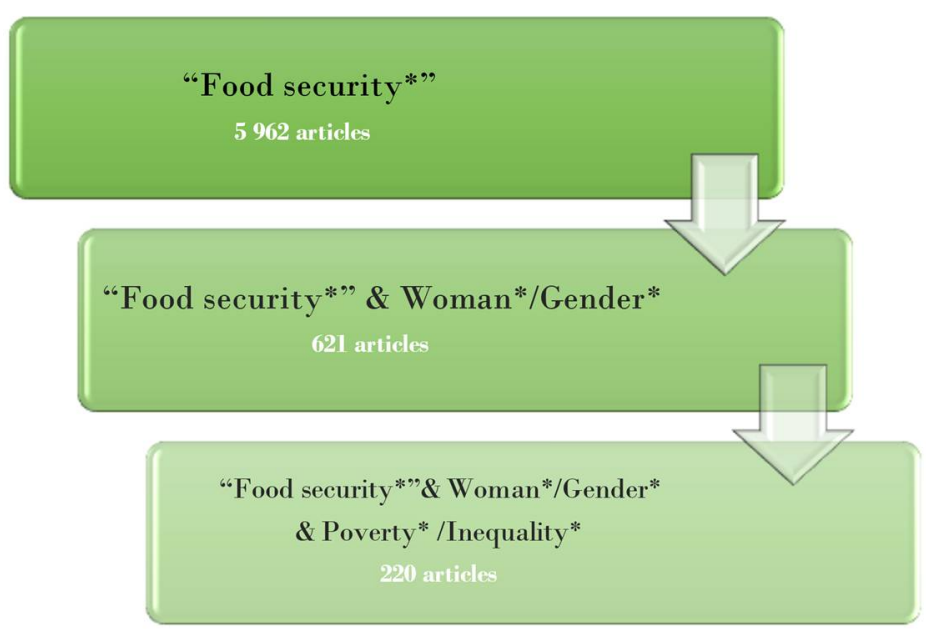

Figure 1. Bibliographical search matrix.

Finally, the ethnographic fieldwork was carried out in the Catalonia region between 2016 and 2019. Although the broader study considers the relationships between different social actors (social workers, volunteers, health professionals and activists), this article focuses solely on those people who underwent a process of precarization as a result of the recession of $2008^{3}$. The members of the research team worked in a variety of different contexts: soup kitchens, parish churches, food banks, supermarkets and public spaces, using direct observation and in-depth interviews (see Figure 2). The selection criteria that were specified for informants included people who were responsible for feeding themselves and/or their family members, and who had applied for and received some form of food aid and social assistance. The 56 informants selected were adults who live alone, with other family members, or in shared accommodation. Of these, 44 were women and 12 were men, with an average age of 50 . In total, 41 of them received or in the past had received food parcels. The majority were unemployed. Those in work had temporary occupations and many worked in the informal economy, earning low salaries. Retired people were also included if they had economic responsibilities for family members, often their children or adult grandchildren. Of the respondents, 18 informants were living in Barcelona, 17 in Tarragona, 14 in Reus, and 7 in other cities. As regards nationality, 14 were foreigners, all of them female non-EU citizens.

The narrative approach, focusing on the relationships between individual experience, cultural context and the construction of meanings (Garro and Mattingly 2001), was applied by means of biographical interviews that elicited experiences of food deprivation in order to shed light on how people with limited resources navigate the continuum between food security and insecurity. The verbatim transcriptions of the interviews were digitalized using the ATLAS.ti program (ATLAS.ti Scientific Software Development GmbH, Berlin, Germany), which facilitated data analysis by identifying the topics that emerged from the practices and pathways by which people obtain food for themselves and their families (Table 1). A coding protocol was created by consensus among the research team members, with the resulting 53 concepts and labels classified into the five categories on which the analysis is based: precarization, food strategies, support programs, interlocutors and support networks, and state of health. 


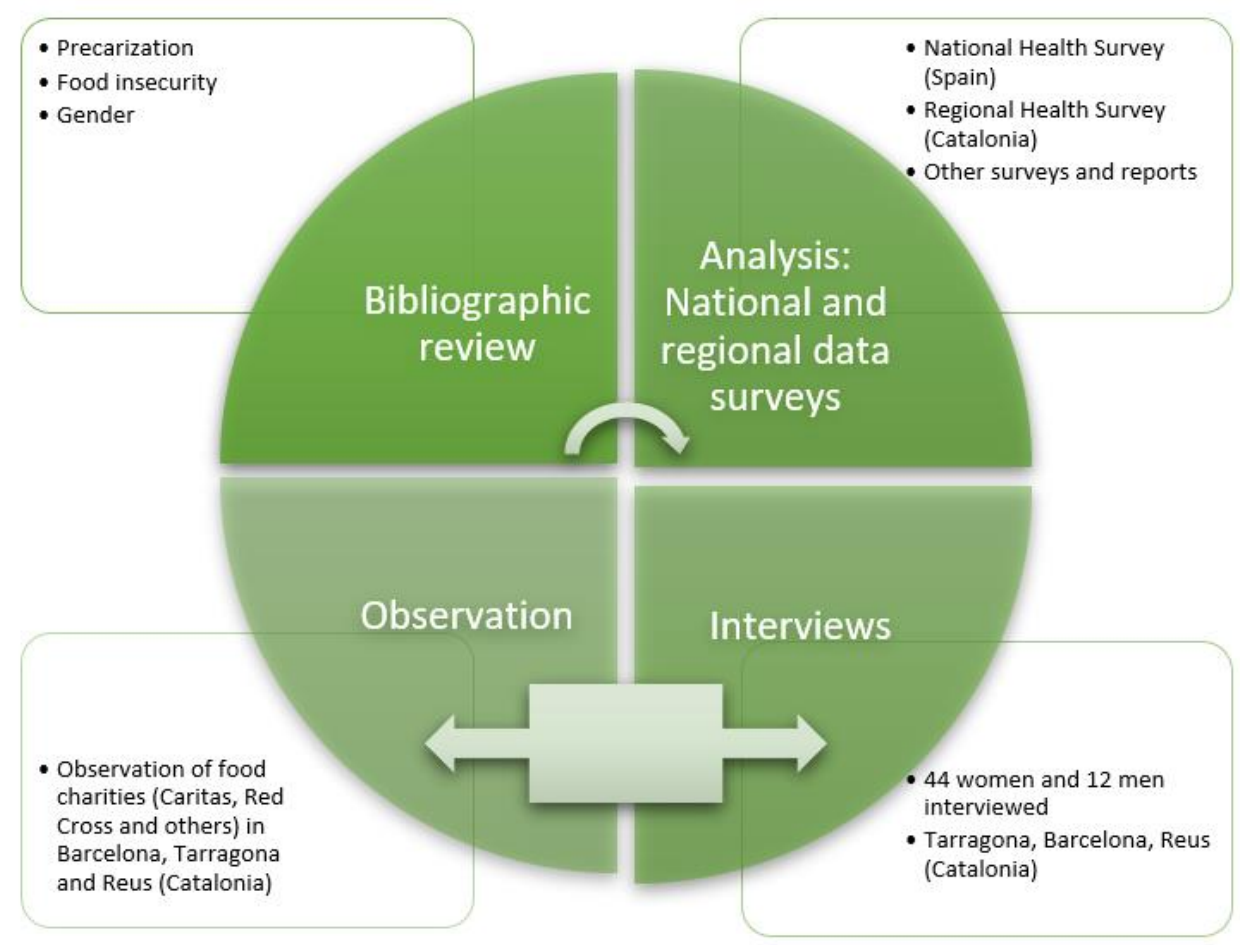

Figure 2. Methodology and sources of information.

Table 1. The coding matrix used in ATLAS.ti.

\begin{tabular}{|c|c|c|}
\hline Topics & Analytical Categories (Codes) & Cross-Categories \\
\hline Precarization process & $\begin{array}{l}\text { Suffering, impoverishment, uncertainty, casualization, underemployment, } \\
\text { non-contributory benefits, difficulty in paying bills, low wages, informal economy, } \\
\text { housing conditions, financial help, food assistance }\end{array}$ & \multirow{11}{*}{$\begin{array}{c}\text { Spaces, access, } \\
\text { temporariness, } \\
\text { gender (identifying the } \\
\text { gender of the subject, } \\
\text { gender analysis), health, } \\
\text { social class }\end{array}$} \\
\hline $\begin{array}{l}\text { Individual and collective } \\
\text { responses to precarization }\end{array}$ & "empowerment", activism, agency & \\
\hline Food security-insecurity & $\begin{array}{l}\text { Irregular access to food, access to healthy food, food quality (condition of food), } \\
\text { varied diet, household food management, food origin }\end{array}$ & \\
\hline Excess weight-precarity & quantity of food, quality of food, emotional health, physical activity, eating habits & \\
\hline Food itineraries & $\begin{array}{l}\text { Institutional circuits, neighborhood circuits, formal-informal itineraries, soup } \\
\text { kitchen, parish church, Caritas, municipal spaces, community supermarket, food } \\
\text { bank, supermarkets, allotments, market, street market }\end{array}$ & \\
\hline Food strategies & $\begin{array}{l}\text { Type of food (cheaper products, pre-cooked, fresh, processed, ultra-processed), } \\
\text { purchase of food (changes in the place of purchase) }\end{array}$ & \\
\hline $\begin{array}{l}\text { Gastro-anomic- } \\
\text { gastronomic } \\
\text { structures }\end{array}$ & $\begin{array}{l}\text { Mealtimes, eating spaces, access to kitchen, food over the day (number of meals, } \\
\text { type of meals, time of meals, eating places, eating with others, time spent cooking) }\end{array}$ & \\
\hline Formal support networks & $\begin{array}{l}\text { Community organization, social services, businesses with CSR (restaurants, } \\
\text { supermarkets, etc.), NGOs, AMPAS (parent-teacher associations), CAP (community } \\
\text { health centers), etc. }\end{array}$ & \\
\hline Informal support networks & Support from family, neighbors, friends & \\
\hline $\begin{array}{l}\text { Healthcare for excess weight } \\
\text { in precarious situations }\end{array}$ & $\begin{array}{l}\text { Prescribed treatment, diet, diseases associated with precarity (mental health, obesity, } \\
\text { physical pain, malnutrition), physical activity, dietary practices, health intervention } \\
\text { (individual, group, community), social inequality, detecting precarity, community } \\
\text { intervention, health programs, limitations of interventions, protocols }\end{array}$ & \\
\hline $\begin{array}{l}\text { Public policies for } \\
\text { prevention and intervention } \\
\text { (obesity, precarity) }\end{array}$ & $\begin{array}{l}\text { Prevalence of obesity, comparative policy, social variables of obesity, socioeconomic } \\
\text { status (social class), socio-demographic variables (age, gender, etc.), obesity } \\
\text { prevention programs }\end{array}$ & \\
\hline
\end{tabular}




\section{Results}

\subsection{Living in Times of Crisis}

Studies indicate that the impact of the austerity policies implemented by many governments in the wake of the last crisis is an exceptional demonstration of the duality identified by Warde (1997), whereby it is true, on the one hand, that food production is more flexible and particularized than ever; on the other hand, social class, now with more fluid boundaries than in previous eras (Subirats 2012), continues to be the main variable explaining differences. Time has vindicated those of us who from the outset put the term "crisis" in inverted commas when it began to flood political, social and economic discourses in late 2009. We did so in our previous works for various reasons (Gracia-Arnaiz 2019; Gracia-Arnaiz et al. 2021). One of these reasons had to do with our intention to keep our distance from the hegemonic discourse that presented it as an unforeseen situation that had arisen, with a beginning and an end, a cyclical phenomenon that was going to return us to the status quo ante-and soon. Many indicators suggested, however, that this was not a period of temporary instability but rather the consequence of structural changes caused in preceding decades by neoliberal economic policies and cuts in public spending. It has also vindicated those of us who see the problem of insecurity as a political issue linked to the precarization of everyday life, rather than as a specific problem stemming from circumstantial factors related to having a job or not having one (Escajedo et al. 2018). Today, we know that having a job does not preclude being poor; it does not guarantee basic rights, either (Malgesini et al. 2018). In Spain, this last global economic crisis has meant a restructuring of daily life for many people and, at the same time, an institutionalization of uncertainty (Alonso and Fernández 2013). Precarity is no longer an exceptional situation in capitalist societies but rather a current running through them.

As statistical sources and third-sector reports show, the process of precarization has been reflected in Spain in multiple ways. During the crisis that began in 2008, 15\% of the Spanish middle-class population sank and the situation has not recovered since, not to mention the social havoc wrought by the COVID-19 pandemic. While higher-income people have benefited disproportionately from the economic recovery, there are fewer people in the middle classes, and those retaining that status have become poorer, especially if they belong to the lower-middle class, whereas in 2000, they accounted for $37 \%$ of Spanish wealth; in 2014, this percentage fell by ten points (Ayala and Cantó 2018). Although some macroeconomic indicators have improved since 2015, and the rate of unemployment went down to $13.78 \%$ in 2019 , there were still 3.1 million people unemployed. In Catalonia, this unemployment rate reached $13.9 \%$ in 2020. As a result of the COVID-19 outbreak, and after a year of the pandemic, that figure reached 3.6 million in March 2021 (EPA 2019, 2021). In addition, the quality of work has worsened, with more temporary contracts and lower salaries (Fernández 2017). Thus, poverty increased during the crisis by four times more than it had reduced in the recovery, leaving 12.3 million people - or $26.1 \%$ of the population - at risk of poverty or social exclusion (Llano 2019), many of whom were dependent on social assistance to cover their basic needs (Caritas 2016).

In recent years, just before the health emergency caused by the COVID-19 pandemic, the term "crisis" had been replaced by "post-crisis", referring to situations that, although they had led to the recovery and upturn of certain macroeconomic indicators, such as GDP or job creation, reflected the persistence and growth of social inequality and the consolidation of deep social and regional vulnerabilities (Prada-Trigo 2018; Martín 2019). It was, however, a very short-lived expression, as the impact of the pandemic has generated a new and deeper recession, especially in those countries where the health emergency is having the worst effects. In the European context, Spain is one of them, with one of the highest rates of infection $\left(3,915,313\right.$ confirmed cases) and loss of life $(80,997) .{ }^{4}$ We are witnessing a health crisis giving way to a social emergency that once again affects the most vulnerable, ushering in new contexts of poverty and uncertainty.

Among all the OECD countries, Spain is one of the countries that has suffered the most negative economic consequences from the impact of the virus. Indeed, it has emerged as the 
developed country hardest hit by the pandemic-led recession ${ }^{5}$. Government containment measures to curb COVID-19 and prevent the collapse of the Spanish healthcare system have sought to reduce physical and social contact, entailing domestic lockdowns, small/large-scale restrictions on mobility, and occasional periods when those activities not geared toward the production of essential items or goods were suspended. The approval of an IMV (minimum vital income) ${ }^{6}$ and the processing of ERTEs (instruments allowing firms to temporarily suspend/alter workers' contracts), ${ }^{7}$ designed to cushion the effects of this pandemic and in some way subvert the austerity measures imposed by previous governments, are proving insufficient to prevent the erosion of material living conditions (EAPN 2021). Indeed, the income-guarantee system provides little economic protection and only covers $3.6 \%$ of families in poverty (Caritas 2021). For its part, the Spanish statistical office, INE (2021), has provided data indicating that the GDP fell by $11 \%$ in 2020 , a contraction double that experienced in 2009, which has finally pushed the country back into recession, while unemployment figures were the worst recorded for a decade, exceeding 3.6 million. Similarly, the Catalan GDP also decreased by $11.5 \%$ in 2020 , half a point above the national average.

This situation is matched by a very significant increase in the demand for social assistance on the part of citizens. Indeed, as the base of impoverishment has expanded, the welfare model set up to cover basic needs has come under increasing strain. According to Caritas $(2021)^{8}$, the number of applications for help has increased by $57 \%$ since the health crisis began, particularly focusing on food, housing, internet access, and emotional support in dealing with loneliness and uncertainty. Of these applications for help, 33\% came from people requesting it for the first time. The majority were from single-parent families; above all, from women with dependent children. In Catalonia, the impact of the health crisis caused by COVID-19 in 2020 has increased the demand for aid to food banks by $30 \%$, compared to the previous year. The growing precarization over this last decade has been reflected in the changes made to daily food practices, which express the nature of the difficulties encountered, as well as the means that each society establishes to tackle them. In Spain, during this period, the models of food consumption among socially disadvantaged people have remained similar in terms of historically defined issues: being limited in variety, quality and frequency. In a context of growing uncertainty and material deprivation, meeting the basic need to feed oneself has required changes in tactics, environments, and interlocutors. People in precarious situations have used diverse resources that, in numerous cases, have gone beyond the institutional forms of food assistance provided by governments, humanitarian organizations or social services. Even so, in those years in which the base of impoverishment has expanded significantly, the demand for social assistance has overstretched the welfare model designed to cover basic needs.

As has happened in other European countries (Borch and Kjaernes 2016; LambieMumford 2017), the government administration has tried to guarantee the right to food by bolstering and institutionalizing a broad network of non-profit organizations that tend to distribute food to those most in need on the basis—though not exclusively so-of reports produced by municipal social services. In the city of Barcelona alone, there are over 250 organizational bodies dedicated to this end. Supranational institutions, such as the Food Bank, the Red Cross or Caritas are, however, the main bodies that, in collaboration with local authorities, store and distribute the greatest quantity of food. Apart from the capacity of these institutions to circulate agro-industrial surpluses, as occurs with the European FEGA program, other initiatives aimed at reducing deprivation have emerged in recent years. One example is the ministerial strategy, "More food, less waste"(MAGRAMA $2013^{9}$ ), which seeks to prevent and reduce waste generated by the food chain, as well as to promote inter-institutional solidarity through the donation of surpluses to socially disadvantaged people. Other initiatives not focused on food distribution include soup kitchens, cash cards, or catering services. 


\subsection{Feminization of Poverty and Food Insecurity}

According to the literature review, there are numerous studies indicating that the groups at a disadvantage concerning the right to food are those living in precarious situations-women, in particular. The feminization of poverty, a term coined in the 1970s by Pearce (1978), is not only a consequence of a lack or insufficiency of income, but also of gender prejudices existing in many societies that end up finding expression in the denial of access to certain resources and to basic human rights such as education, dignified work, health, or a safe and secure supply of food. Of the total number of impoverished people in the world, $70 \%$ are women and, among those that go hungry on a chronic basis, $60 \%$ are women and children (United Nations 2015). Despite all the gender equality policies adopted in recent decades to redress this situation, the global data suggests that the gap between men and women has not narrowed enough.

In the specific case of Spain, the 2019 FOESSA report (2020) identifies the variable of gender as a determinant of precarity, along with the social stratification that impedes the full incorporation of women in the world of work, and above all their opportunities to rise in the occupational hierarchy, on the basis of three indicators of precarity: temporariness, involuntary part-time working, and the wage gap. It also highlights the fact that in households where the main breadwinner is a woman, higher rates of poverty are recorded. Indeed, the gender wage gap has remained stuck at $22 \%$ in the period from 2009 to 2019 (FOESSA 2020). According to the INE (2018a), 42\% of single-parent households with dependent children are at risk of poverty and, of those, $81 \%$ are headed by a woman. On the other hand, the at-risk-of-poverty or social exclusion rate-the AROPE indicator for 2020, based on pre-COVID-19 data-is at 26\% for women and 24.6\% for men (Llano 2020). According to this indicator, the gender gap also exists among older people, widening notably in this last year, due to the difference in the amount of pension received by men and women. It can, therefore, be stated that in the case of Spain, there is also a feminization of poverty, understood as a process by which the differences between male and female poverty are becoming more pronounced. This corroborates the hypothesis that women, above all older women and widows, continue to be the most vulnerable group (Valls and Belzunegui 2014). Their greater precarization is also due to the fact that they devote more time to the care of sons and daughters, thereby reducing their formal working hours (INE 2018b). The same goes for Catalonia: a higher incidence of poverty is recorded in women (and other vulnerable groups) compared with men. Income has a direct impact on people's living conditions and is not unrelated to gender inequalities. The feminization of poverty is, then, the direct consequence of this situation of greater impoverishment. In 2020, the at-risk-of-poverty rate for Catalan women was $27.8 \%$, three percentage points above the rate of $24.9 \%$ recorded for men as Observatory for Gender Equality (OIG) from Catalonia Government reported (OIG Observatori d'Igualtat de Gènere 2020) (Figure 3).

The literature indicates that poverty predicts food insecurity and that this is more prevalent among women (Martin and Lippert 2012), forming a continuum that runs from anxiety about not having enough money to buy food or to obtain the things they like, to the need to reduce the quantity, variety, and quality. Food insecurity also entails skipping meals or eating them at odd times, modifying the diet and embracing hunger (NRC 2006). Unfortunately, the surveys available in Spain on living conditions do not ask these questions directly, while the FAO annual reports (FAO et al. 2019, 2020) do not provide data that are disaggregated by class, age, gender or ethnicity, either. This masks possible forms of inequality that are often expressed through the disparate distribution and consumption of food among members of the same household group (Neogy 2010). 


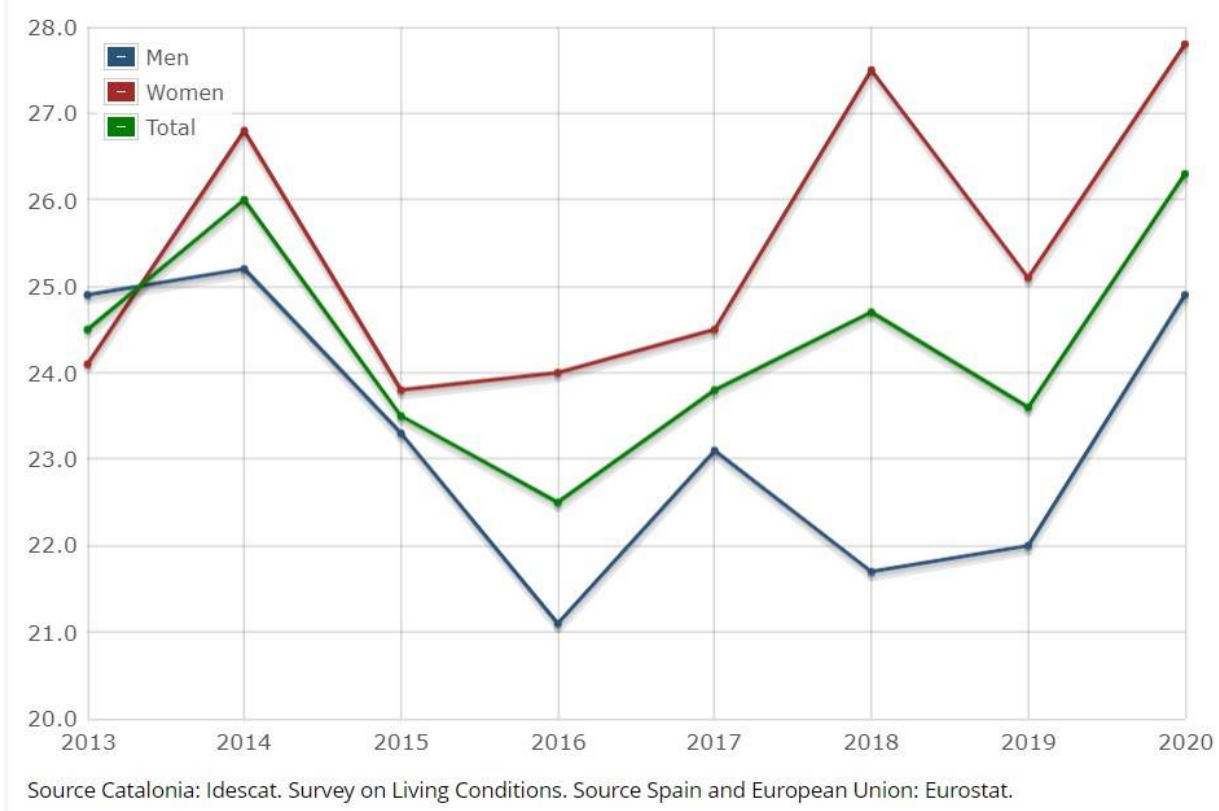

Figure 3. Percentage of the population at risk of poverty or social exclusion. Shown by sex, Catalonia, 2013-2020.

This has been borne out by the ethnographic data. Living through a process of economic contraction and social benefit cuts, with an unstable position in the labor market, places women on this continuum of food security and insecurity. Although the sustained growth in the presence of Spanish women in the non-domestic labor market in the last quarter of the last century constitutes one of the most important changes in recent history, it is still insufficient and concentrates the most precarity. In any case, it has afforded greater visibility to the set of essential activities and knowledge, forming a part of domestic and care work (Comas d'Argemir 1996), that make biological and social reproduction possible. The high number of women employed in elderly care, house-cleaning or childcare is significant. Taking into account the employment rate according to activity, $5.4 \%$ of active women work in the domestic sector (cleaning and care), versus $0.6 \%$ of men in 2020 . Ten years ago, the average rate for women in this sector was $8.1 \%$, with men at the same rate of $0.6 \%$ (INE 2021). However, these are jobs with short or long but discontinuous hours, low wages, and often with no contract, placing them in a secondary position in the labor market. Often, having to carry the dual burden of working within the home as well as outside makes it difficult for these women to manage their own meals and self-care optimally, and they suffer physically and emotionally (Offenhenden 2017).

According to the data collected from the ethnographic fieldwork, within household groups, the organization of tasks is also marked by the sexual division of labor. It is mainly women who lead or coordinate those activities connected with the management of food and with responses to diminishing resources on which to survive, thus enacting another form of inequality. Faced with a loss or lack of income, men devote more time to searching for work outside the home, while women seek help in their social support networks so they can meet expenses, such as the paying of utility bills, rent, or mortgages. According to Red Cross reports, hardship is more acute among women in the population receiving food aid: "They have higher rates of severe material deprivation than men on average and in almost all age groups" (Malgesini et al. 2018). Thus, when living conditions become precarious, they activate various resources in an effort to cover basic needs.

As the primary managers of daily food provision, women take the initiative when it comes to seeking assistance, both formal and informal. Collectively, they cover a wide range of tactics and interlocutors. In many cases, they first opt for the support of relatives, friends, or near neighbors: "First I turned to my sisters because I didn't know where to go 
and they weren't going to refuse me a plate of food" (woman, 53). Where such support networks exist, they usually receive help in the form of groceries or prepared food, and also through care for younger children: "My parents collect the kids from school and feed them every day, and me too if it comes to that" (woman, 42). Women also tell of receiving loans or financial donations from family or friends. Some report having been accompanied to the shops and their purchases being paid for, or even doing odd jobs and receiving food in return.

Those with a weaker support network more often seek assistance from public or charitable organizations. In the food queues at the parish churches or neighborhood associations where we have visited, there were many more women than men, which agrees with the results of the study carried out by the Red Cross (Malgesini et al. 2018), according to which $70 \%$ of people receiving food from the Fund for European Aid to the Most Deprived (FEAD) are women, many of them from households with children. All those who form part of our study have received food aid from charitable organizations or the government, depending on its assistance for months and even years if their socioeconomic situation does not improve (Table 2). Most of them report having felt shame or frustration before taking this step, including a certain reluctance to acknowledge the vulnerability to which they are prey that has prolonged such situations of deprivation. It is very common for older women to delay or even avoid requesting help, especially if they live alone: "I have a very small pension but I don't eat much, either. It was the social work lady who told me they were going to bring me meals on wheels" (woman, 71).

Another of the resources most in demand is assistance in the form of the "beca comedor" (dining grant), where the government covers all or part of the cost-depending on household income-of children's school meals (Table 2). Formal food aid provided by charities and neighborhood social organizations is also prominent. Caritas-with its parishes and social supermarkets as food distribution points-and the Red Cross are the most common. However, in every city, multiple initiatives have sprung up, such as soup kitchens and foundations-among other charitable bodies-that provide meals or distribute food on a regular basis. The help received in the form of food parcels can include fresh fruit and vegetables, along with non-perishable foods such as rice, pasta, pulses, cookies, milk, juices, tinned produce, or oil. Fresh produce is less common and depends on the season, the surpluses of agrifood businesses, and both private and public contributions to food banks. Most of the food parcels are collected by users once a fortnight and are meant to cover $50 \%$ of the household's monthly food requirements. In other words, the logic governing this resource is to provide support but not necessarily to guarantee the right to adequate food. People need to develop strategies to complement their daily food rations until they receive the next parcels, or to obtain fresh products, such as vegetables, fruit, meat or fish. In many cases, this means reaching the end of the fortnight or month with very little food. Guaranteeing the right to food is thus not the main purpose of these initiatives.

One highly valued resource is the provision of so-called "tarjetas monedero" (purse cards), which are debit cards made available to the head of the household so they can do their own shopping for food and basic products (Table 2). A maximum monthly amount of money is allocated, and purchases are subject to checks. On the one hand, it avoids stigmatization and offers exemption from "shame" because it enables access to commercial outlets without having to reveal one's circumstances; on the other hand, the amount continues to be insufficient if there is no other income. A Caritas social worker explains: “There are prepaid cards for shopping, and they have two functions. If people don't have a regular legal status or if their account has been seized, they can't get money, but this way, they can go and buy what they want in supermarkets. In reality, it is just a symbol because there should be a genuine guaranteed basic income for citizens to take the place of all of this ... We are fighting against the image of the poor as stupid and corrupt". For this particular third-sector worker, food aid is a short-term solution and does not ease the stigma of poverty. 
There is other assistance available, such as the new IMV or other minimum-income supplements. On occasion, users of Caritas, the Can Pedró Foundation (Barcelona) or the M. F. Bara Foundation (Reus) also receive support to cover the costs of their rent or mortgage, medicines, or healthcare benefits, thus complementing the food aid.

Table 2. Formal food aid services used.

\begin{tabular}{|c|c|c|c|c|}
\hline Service & Food Aid Received & Organization & Organization Type & City \\
\hline Purse card & $\begin{array}{l}\text { Debit card to buy food and other } \\
\text { essentials }\end{array}$ & Barcelona City Council & Public administration & Barcelona \\
\hline Social supermarket & $\begin{array}{l}\text { Fortnightly food parcels (including } \\
\text { fresh and frozen products) }\end{array}$ & $\begin{array}{l}\text { DISA Sant Andreu, } \\
\text { Caritas }\end{array}$ & $\begin{array}{c}\text { Charitable organization } \\
\text { linked to the Catholic } \\
\text { Church }\end{array}$ & Barcelona \\
\hline Soup kitchen & $\begin{array}{l}\text { Weekly food parcels and several } \\
\text { days' worth of food in Tupperware } \\
\text { (including fresh produce). }\end{array}$ & Gregal soup kitchen & $\begin{array}{l}\text { Neighborhood social } \\
\text { organization }\end{array}$ & Barcelona \\
\hline Soup kitchen & $\begin{array}{l}\text { Lunch from Monday to Friday, } \\
\text { takeaway meals (weekends) }\end{array}$ & $\begin{array}{l}\text { Bonavista soup kitchen } \\
\text { (Joventut i Vida } \\
\text { Foundation) }\end{array}$ & Foundation & Tarragona \\
\hline Soup kitchen & $\begin{array}{l}\text { Lunch Monday to Friday, takeaway } \\
\text { meals (weekends and dinner) }\end{array}$ & Can Pedró Foundation & Foundation & Barcelona \\
\hline $\begin{array}{l}\text { Food parcels and } \\
\text { children's canteen }\end{array}$ & $\begin{array}{l}\text { Fortnightly food parcels. } \\
\text { School meals }\end{array}$ & $\begin{array}{l}\text { Mossén Frederic Bara } \\
\text { Foundation }\end{array}$ & $\begin{array}{l}\text { Charitable Christian } \\
\text { foundation }\end{array}$ & Reus \\
\hline Food parcels & Fortnightly food parcels & Tarragona Red Cross & NGO & Tarragona \\
\hline
\end{tabular}

\subsection{Food Itineraries as a Expression of Increasingly Precarization}

As for the changes seen in food itineraries during ethnographic fieldwork, residential and dining patterns are reorganized to save money in the preparation of food and/or to ensure that there is enough food for all members of the family, in an effort to mitigate the effects of food insecurity. There are families living in separate accommodation who form a single group to reduce essential costs. In other cases, several family units get together to make the midday meal in one home. The most common arrangement is for sons, daughters and grandchildren to have lunch in their grandparents' house while living in another property. One woman recounts how lack of money drove her to take her son to her mother's house to be fed at least twice a week. The women report significant changes that go beyond modifications in eating places and groups or family reorganization. They try to cut costs and obtain the foods that best fit their culinary skills and knowledge, but do not always succeed. The circuits of provision have changed significantly, due to precarization. In general terms, this means more frequent shopping to buy food in small quantities, swapping their usual outlets for other, cheaper ones, even if they are further away, or taking up special offers on products not previously consumed: "I used to go to Carrefour ... and they would bring my shopping to the house ... but not now, now I buy small amounts, day by day so to speak" (woman, 43). They also buy own-brand products and cheaper meat and fish, especially frozen fish. Among the supermarkets they have abandoned because of their high cost, Carrefour and Caprabo stand out. By contrast, the shops most popular for their low prices are Día, Lidl and BonArea. Halal butchers also feature for the good quality/price ratio of their meat products and trips to the local or municipal market in the last hour of the morning's trading when they get products at reduced prices. In Tarragona, they mention the weekly street market in the Bonavista neighborhood, selling products such as fruit, vegetables, or clothes at lower prices than elsewhere in the city. However, all of this depends on each individual situation, as there are people who cannot afford even a minimal shop on a regular basis. What is more, these 
trips are often accompanied by the fortnightly collection of food parcels from Caritas, the Red Cross, or other bodies.

The strategies seek to reduce costs and optimize spending, while at the same time reproducing the existing dietary pattern, paying special attention to children's consumption. The daily food timetable is organized into four meals for children and two, sometimes three, for adults. More substantial stews are prepared, so that food is available for several days while saving on gas and electricity, and meat is rationed: "Although there isn't much meat, the dish tastes of meat" (woman, 43). These are usually meals to satisfy the appetite and then, if possible, the palate. They imitate recipes that include similar ingredients, but it is not easy to replicate dishes, flavors and textures: "You use your imagination. When you have several packets of macaroni or pulses, you try to cook them differently. Sometimes in a cold salad, then in a Bolognese sauce but without meat ... but it's not the same, of course" (woman, 42). In situations of insecurity, improvisation informs the food itineraries, making them more complex and often requiring a greater investment of time and effort, as they have to source food and find out who can provide it in one form or another. This difficulty abates when the resources are available outside of the home, in school canteens or via catering services.

These are itineraries that involve, in any case, the broad deployment of support networks. A paradigmatic case is a household formed of several regrouped family units. There are three older people living together (a couple and a brother-in-law), who at the height of the recession took in their daughter, husband and two grandchildren from Venezuela. The household group went from two to seven people in a short space of time. The daughter, aware of the precarity her parents were experiencing through lack of work, decided to go to Caritas to ask for assistance. The older generation had not done so before out of shame. As the household representative, the daughter gets not only to benefit from fortnightly food parcels but also to attend a home economics course on optimizing culinary resources. Her arrival means changes in the daily menus, so as to adapt them to the products in the parcels received and reduce spending on electricity and gas. It also prioritizes the sharing-out of the meat and fruit obtained among the children, as a matter of urgency. In a matter of months, this woman not only acquired a regular source of food but also the know-how to make the dishes more appetizing. Over the same period, and with the support of Caritas, she and her husband began training as home care assistants entitled to apply for a job in this sector.

Ways of preparing food differ according to gender. Men cope with food insecurity in a different way. Rather than devising appetizing and dishes that are as healthy as possible with fewer or more filling ingredients, they opt for cheap pre-cooked or frozen dishes: boiled lentils, pizza, or pre-cooked rice: "You buy a pot of lentils or a pizza, or I don't know, that ready-made stuff with potatoes and bits of meat or frozen three-delights rice, you heat it up in the frying pan and eat it. We buy a loaf of bread every day and it's gone ... We used to eat three courses" (male, 53). Another male, a 68-year-old resident of Tarragona who lives alone, showed us his fridge. The products were mainly pre-cooked purées, juices, cold meats and cheese, and sliced bread. He hardly cooks and uses the microwave and toaster more than the kitchen stove. Men look for quick satisfaction in a meal, and women try to make dishes with similar but cheaper ingredients. In the soup kitchens of Tarragona and Barcelona, we saw more men than women, and in the queues to receive food parcels at the parish churches, it was the other way around. Men try to get their food in any way they can, without bothering about variety or healthiness-especially if they live alone-and devote more time to seeking work outside of the home and/or working if they can. However, the presence of women at these centers has increased, coinciding with the impact of the economic and health crisis. Sometimes they resort to this service because they have no space to cook, or because they live in one room and/or do not have access to a kitchen. Women who come to the soup kitchens for meals do so at midday, sometimes alone or accompanied by their children, and may receive complimentary dishes cooked for dinner and/or the weekend. 
The weekly diaries of women living in single-parent households record very frugal morning intakes, based on coffee and bread or juice, or even just a coffee for the whole morning. Between meals, both men and women identify bread as a cheap and filling product, one that can form the basis of an evening meal, accompanied by a little cold meat or cheese. Differences in consumption between children and adults can also be seen in the diaries. Women eat less than men and, above all, much less than their children: "Yes, you always leave it for your children ... because you are a mother you know ... if you want to eat a piece of fruit, you look at them and say, no, I'm going to leave it to them. No, I'm not going to eat, I'm going to leave it to my children. That's happened to me lots of times" (woman, 29). They explain that they are not so hungry, that "they've never eaten that much", or also that they prefer to eat less for the sake of their children: "Look, I ... meat, for example, meat, it's definitely off the menu for me. I don't buy it. And for my son, I buy it once a week. Just once a week... I always give him a Catalan sausage to go with it ... whereas I have it with rice: I stir it all around with rice and a bit of tomato and that's it" (woman, 49).

In the most precarious households, meat and fish — even vegetables and fresh fruitcan sometimes barely feature: "When you pay the rent, the electricity and the water, halfway through the month, what's run out? Well, money. I ate badly. At home, my parents and my siblings made breakfast, lunch and dinner, but without meat. Caritas gave us a lot of pasta, rice and that kind of food. That's what we ate. Almost no meat, much less than before, every ten days. We didn't even buy fish, impossible. We didn't eat well. They ate together, but I went to study and then to clean a house. Then I got another one. I was there for 4 or $5 \mathrm{~h}$ and I got 10 euros for the whole day. As the situation was what it was, I did it. With those 10 euros, I bought food, especially for the children" (woman, 24).

Food parcels distributed from food banks lack meat, fish and fresh fruit and vegetables, as the 2007-2019 Federación Española de Bancos de Alimentos reports point out (FESBAL 2019). Furthermore, the reports and statistics provided by this Federation and Caritas are not disaggregated by sex or age, so we do not have quantitative data that would indicate the percentage of women receiving food parcels, which would help us to determine the incidence of food insecurity in Spanish women from 2008 to the present.

The 24-year-old woman was 16 when she lived through this situation. The food aid from Caritas and the local Civic Center did not prevent her performance at school from deteriorating. Seeing her mother suffer from not having enough food for her children and husband spurred her on to work. There is no doubt that her meager income, together with what her father earned in his precarious jobs, helped to alleviate their food insecurity, but their combined wages were not sufficient to cover all their expenses or to lift the feeling of guilt at not being able to do more.

\section{Discussion and Conclusions}

In a context informed by economic recession and health crisis, in Spain, the state and regional authorities have normalized a failure to guarantee the fulfillment of fundamental rights and government through uncertainty. The statistics and ethnographic data show that, since 2008, the precarization of daily life has found diverse expressions, but particularly through the increasing difficulties that a significant part of the population has faced in meeting basic needs: access to proper housing, a decent job, or adequate food. This process of precarization is similar to that which has occurred in other European countries (Vasco Ramos Vasco et al. 2020; Pfeiffer et al. 2015) and, as elsewhere, it is the main cause of the rise in food insecurity. As we have discussed previously (Gracia-Arnaiz 2017), the pressures exerted on people's lives (tax increases, co-payment for health services, salary decreases) by the current demands of governments in order to decrease public expenses raise serious obstacles to eating better. Daily demands placed on many people do not allow for a healthier and more balanced diet, at least not to the extent that health authorities would like to see, because changing diet means changing lifestyles, which can be very difficult if not impossible for those living in the most precarious situations. In barely a decade, in 
Catalonia, there has been a tripling in the number of people having to seek food aid to subsist from family and friends, humanitarian organizations and social services. Although this precarization affects many people, it has materialized most strongly in particular groups, among whom specific forms of exclusion intersect. Such is the case with women, migrants and older people. As the literature indicates (Broussard 2019), understanding how the interlocking systems of gender, social class, or ethnic origin connect up with each other is key, as food insecurity often arises when marginal identities intersect.

It is surprising that so little attention has been paid by the Spanish and Catalan governments' agenda to the effects of the growing impoverishment of certain groups regarding food insecurity. This is partly due to limited political interest in the phenomenon and, as a corollary, in the methodological tools that administrations have at their disposalor not-for recognizing and evaluating it. In contrast to countries such as the United States (Patterson et al. 2020; Ma et al. 2021), in Catalonia and in the rest of Spain, we are very far from knowing the extent of food insecurity and how it manifests unequally in the gender system. Most of the reports that discuss food insecurity in this country refer to the risks it might pose for public health in terms of the food chain - with nothing about the problems stemming from differential access to resources. In other words, we have reports and statistics on the agrifood market in the context of economic constraint but learn nothing about what happens in homes that have to grapple with difficulties in the regular and independent access to food. We know from FAO reports that food insecurity increased by more than $15 \%$ between 2018 and 2019 but, unfortunately, they do not provide information on differences in the prevalence of food insecurity among men and women, different ages, or ethnic origins.

This institutional invisibilization of food insecurity and its social distribution underlines the need to analyze it from the feminist/gender perspective (Sachs and Patel-Campillo 2014), as it appears in contexts where there are disparate power relationships (Broussard 2019). Ethnography makes this clear in Spain and particularly in Catalonia. In the first place, it has been seen here that food insecurity constitutes a process/continuum that is often neither detected nor visible. This is partly because it is confined to domestic and care work, which in many cases is imperceptible or undervalued. Daily food provision is organized, nevertheless, on the basis of a complex set of knowledge and caring skills that are indispensable for the reproduction of the workforce. It involves numerous activities that are hard to quantify in terms of time and effort, although they are not, therefore, negligible. To feed is to nourish, care, educate, exchange, work, or feel (Gracia-Arnaiz 2015). It is usually women who feed people during the first months of their life and who, in many societies, end up taking care of their food needs while they remain in the family group, or even after ( $\mathrm{O}^{\prime}$ Connell and Brannen 2016). In this regard, the family, in whatever form it takes, plays a key role-although not an exclusive one-in the transmission of food know-how and the identification of gender roles.

In the family sphere, when money is tight, women deal with the shortage of food because gender expectations largely put the onus onto them. They are the main providers, cooks, and distributors of food, and adapt their tactics by mobilizing all available resources. This responsibility is even more evident in cases where there are young children or other dependents and in single-parent families, given the dominant model of care: the responsibilities multiply and the sexual divisions of labor and care become even more unequal. In domestic groups, this inequality ends up assigning women the primary responsibility for satisfying nutritional needs and taking care of their families. In this sense, their continued importance in the daily provision and preparation of food and in the management of material deprivation is also confirmed in Spain.

Food itineraries have proved to be a highly useful analytical category, both for identifying situations of food insecurity and for showing that this is most prevalent in women. They offer an exceptional illustration of the changing nature of the practices and knowledge that women deploy in each situation/stage and emphasize the path they take through all the formal/informal support networks. Therefore, they are also a good tool for showing 
the specificity and relevance of food know-how in social reproduction. Women have to reorganize and adapt their knowledge and culinary skills to the life changes that they face. These changes affect the whole pattern of food consumption: shopping in places with better prices but lower quality, the type of products bought also changing, with more affordable ones (own-brand and/or frozen or processed) being sought out, eating at home to avoid extra expenses, and regulating the consumption of electricity and gas through ingenious cooking methods. If the difficulties mount, it is the women who seek out support in their informal networks and, if necessary, take on the job of applying for assistance from social services or non-profit organizations. These bodies try to establish more dignified ways of obtaining food, so as to veil the stigma of being recognized as poor and dependent. This explains the success of the purse card, money payments into bank accounts, or the points system for shopping in supermarkets. Men, however, are more reluctant to avail themselves of family or neighborhood networks, turning mainly to social services to access soup kitchens or to catering companies, so that they do not have to buy/cook their own meals.

Gender differences also express themselves in consumption. As happens all over the world (FAO et al. 2019), it is women who are most likely to experience situations of food insecurity. They eat less meat and fish per week than the other members of the household, they skip meals or reduce their content. Even so, they try to reproduce the content of the old eating regimes, striving to preserve, as far as possible, the same methods and ingredients. It is the adult women who eat less and poorly from a nutritional point of view. The underlying responsibility of their caregiving role drives them to offer part of their food to the rest of the family, especially if there are children in their charge. Many mothers sacrifice what is on their plates, cutting back for the benefit of their growing children. "My children first" is a recurrent phrase. With the foods that they buy, receive, or find, they try to create or reproduce meals that match the models of consumption prior to the crisis, both in terms of ingredients and the structure of the menus, timetable and table seating. However, such reproduction, except in soup kitchens or school canteens, is not always possible as changes in the types of food obtained, places of consumption or preparation, timetables, or the number of people around the table affect the whole eating pattern. When the supply of food is limited or uncertain, people improvise using the resources available, sometimes substituting with cheaper or lower-quality foods, sometimes eating less, adjusting the distribution of food among family members, or even eating foods not previously regarded as edible. Some of these solutions involve suffering, with economic and social impoverishment being experienced as the inability to meet basic needs independently.

Policies aimed at improving food insecurity must focus on reducing gender inequality, especially in the areas of work, education, and the home. We have seen that the problem is more acute in women because economic precarization affects them more intensely. Those working in the most precarious sectors (domestic service, home care) have poorer working conditions in terms of hours and wages, which places them in a situation of greater socioeconomic uncertainty and, hence, insecurity when it comes to covering basic needs. Since the training and employment options offered by social services and agencies are directed toward the low-paid job market, food insecurity can be expected to become even more normalized in the coming years.

The Spanish authorities should stop treating food insecurity as a temporary emergency situation (Pérez de Armiño 2018), and respond with effective economic and social policies that apply an intersectional approach, with a special focus on gender and social class. It is not enough to collect and distribute among those most in need the foods bought by the administration, donated by companies, or obtained by humanitarian organizations. While it is true that these institutions help to safeguard the right to food, a type of vertical solidarity still prevails (Riches and Silvasti 2014) that relieves the symptoms of precarization without transforming its causes. At the same time, the institutionalization of food insecurity diverts social pressure from the state and makes people dependent on the resources offered by organizations emerging/burgeoning under the social emergency. This finds 
concrete expression in the many women who have normalized the use of these services as a regular resource. We urge that instead of trusting solely in the redistribution of surpluses generated in the food chain, or in the purchase of food on state/international markets, governments implement policies that contribute to the social welfare of the whole population by guaranteeing access to affordable housing and decent jobs, extending the minimum living wage, and promoting adequate and affordable food.

From the results of this study, it is clear that there is a need for both increased research in food insecurity and greater political attention. In Spain, there are many gaps that need to be examined. We know little about the sociodemographic groups who are most at risk, the social use of new emergency programs, or the impact on health. The challenge in investigating food insecurity in women is not only to make visible their crucial roles in food security and their contribution to it but also to show how the precarization process manifests itself unequally across the household. An intersectional approach can be useful to identify and document disparities in food insecurity and food assistance.

This research has some limitations. We would have preferred to have interviewed an equal number of men and women, as an important aspect of this work has been to analyze food itineraries according to gender. However, the requirement that the persons interviewed be responsible for the household's food has inevitably restricted the number of men. We also recognize that it is a limitation of this study not to have transcended gender categories other than the binary ones.

Author Contributions: M.G.-A. conceived of the presented idea and developed the theory. M.G.-A., M.C. and M.G.-O. contributed to the design and implementation of the research, to the analysis of the results and to the writing of the manuscript. All authors have read and agreed to the published version of the manuscript.

Funding: This research was funded by Ministry of Science and Innovation, Spain, grant number CSO2016-74941-P. APC was supported by ISTHIA from the Université de Toulouse-Jean Jaurès.

Institutional Review Board Statement: The research project was evaluated positively by de Ethical committee from Department of Anthropology, Philosophy and Social Work of Universitat Rovira i Virgili.

Informed Consent Statement: Informed consent was obtained from all subjects involved in the study.

Data Availability Statement: The study did not report any data.

Conflicts of Interest: The authors declare no conflict of interest.

\section{Notes}

INE, Instituto Nacional de Estadística. https:/ / www.ine.es/jaxiT3/Datos.htm?t=10011 (accessed on16 May 2021).

2 Idescat. Institut d'Estadística de Catalunya. https:/ / www.idescat.cat/indicadors / ?id=anuals\&n=10412\&lang=es (accessed on 16 May 2021).

3 However, some references from professionals have also been used to support the arguments put forward by people living in precarious situations.

4 Ministry data from 7 July 2021. https:/ / www.mscbs.gob.es/profesionales/saludPublica/ccayes/alertasActual/nCov/situacionActual. htm (accessed on 1 July 2021).

5 https:/ / d500.epimg.net/descargables/2021/03/09/f7fac84299f53d552054762b79091967.png (accessed on 29 June 2021).

6 The IMV was approved by Royal Decree Law 20/2020, of 29 May.

7 ERTE, Expediente de Regulación Temporal. Approved in Royal Decree Law 8/2020, of 17 March 2020, and modified in the RD Law 30/2020, in September of that same year.

8 https://www.caritas.es/noticias/caritas-acompano-en-2019-a-24-millones-de-personas-mientras-la-covid-19-dispara-un-57-lasayudas / (accessed on 2 June 2020).

9 https://www.mapa.gob.es/es/alimentacion/temas/estrategia-mas-alimento-menos-desperdicio/bloque1.aspx (accessed on 7 July 2021). 


\section{References}

Alonso, Luis Enrique, and Carlos Jesús Fernández. 2013. Debemos aplacar a los mercados: El espacio del sacrificio en la crisis financiera actual. Vinculos de Historia. 2: 97-119.

Ayala, Luis, and Oscar Cantó. 2018. Ciclo económico, clases medias y políticas públicas. In Tercer Informe Sobre la Desigualdad en España. Madrid: Fundación Alternativas.

Borch, Anita, and Unni Kjaernes. 2016. Food security and food insecurity in Europe: An analysis of the academic discourse (1975-2013). Appetite 103: 137-47. [CrossRef]

Bramall, Rebecca. 2013. The Cultural Politics of Austerity: Past and Present in Austere Times. Palgrave Macmillan Memory Series; London: Basingstoke.

Broussard, Nzinga H. 2019. What explains gender differences in food insecurity? Food Policy 83: 180-94. [CrossRef]

Caritas. 2016. Fràgils. L'alimentació com a dret de ciutadania. Barcelona: Caritas.

Caritas. 2021. Un año Acumulando Crisis. La Realidad de las Familias Acompañadas por Cáritas en Enero de 2021. Observatorio de la Realidad Social, Col. La crisis de la Covid-19, núm. 3. Madrid: Caritas.

Comas d'Argemir, D. 1996. Antropología Económica. Barcelona: Ariel.

EAPN, European Antipoverty Network. 2021. Valoración de las nuevas medidas del Ingreso Mínimo Vital. Informe de posicionamiento EAPN España. Madrid: EAPN. Available online: https:/ / www.eapn.es/publicaciones (accessed on 12 July 2021).

EPA. 2019. Encuesta de Población Activa. Available online: https:/ /www.ine.es/daco/daco42/daco4211/epa0419.pdf (accessed on 10 March 2020).

EPA. 2021. Encuesta de Población Activa. Available online: https://www.ine.es/dyngs/INEbase/es/operacion.htm?c=Estadistica_C\& cid=1254736176918\&menu=ultiDatos\&idp=125473597659 (accessed on 7 May 2021).

Escajedo, Leire, Alberto López-Basaguren, and Esther Rebato Ochoa, eds. 2018. Derecho a una Alimentación Adecuada y Despilfarro Alimentario. València: Tirant lo Blanch.

FAO, Organización Panamericana de la Salud OPS, World Food Programme WFP, and United Nations International Children's Emergency Fund UNICEF. 2019. Panorama de la Seguridad Alimentaria y Nutricional en América Latina y el Caribe 2019. 135. Licencia: CC BY-NC-SA 3.0 IGO, Santiago: Food and Agriculture Organization, FAO.

FAO, Fondo Internacional de Desarrollo Agrícola FIDA, World Food Programme WFP, United Nations International Children's Emergency Fund UNICEF, and World Health Organization, WHO. 2020. El Estado de la Seguridad Alimentaria y la Nutrición en el Mundo. Available online: http:/ / www.fao.org/3/ca9692en/online/ca9692en.html (accessed on 15 March 2021).

Fernández, Daniel. 2017. Los salarios en la recuperación española. Cuad Info Econ 260: 1-12. Available online: https://www.funcas.es/ Publicaciones /Sumario.aspx?IdRef=3-06260 (accessed on 4 May 2020).

FESBAL Federación Española de Bancos de Alimentos. 2019. Memoria Anual (Serie 2017-2019). Madrid: FESBAL. Available online: https:/ / www.fesbal.org.es / memorias-anuales (accessed on 2 June 2021).

Fischler, Claude. 1995. El (H)Omnívoro: El Gusto, la Cocina y el Cuerpo. Barcelona: Anagrama.

Fundación FOESSA. 2020. Análisis y Perspectivas 2020. Distancia Social y Derecho al Cuidado. Caritas. Madrid: Fundación FOESSA.

Garro, Linda C., and Cheryl Mattingly. 2001. Narrative as construct and as construction: An introduction. In Narrative and the Cultural Construction of Illness and Healing. Edited by Cheryl Mattingly and Linda C. Garro. Berkeley: University of California Press, pp. $1-49$.

Gracia-Arnaiz, Mabel. 2015. Comemos lo Que Somos. Reflexiones Sobre Cuerpo, Género y Salud. Barcelona: Icaria.

Gracia-Arnaiz, Mabel. 2017. Taking measures in times of crisis: The political economy of obesity prevention in Spain. Food Policy 68: 65-76. [CrossRef]

Gracia-Arnaiz, Mabel. 2019. Eating outside the home: Food practices as a consequence of economic crisis in Spain. In Food and Sustainability in the Twenty First Century. Edited by Paul Collinson, Iain Young, Lucy Antal and Helen Macbeth. Oxford: Berghahn Books.

Gracia-Arnaiz, Mabel, Lina Casadó-Marin, and Mireia Campanera. 2021. Antropologías del hambre: (in)seguridad alimentaria en contextos de precarización. Revista de Antropología Social 30: 2.

Hernandez, Daphne C., Layton M. Reesor, and Rosenda Murillo. 2017. Food insecurity and adult overweight/obesity: Gender and race/ethnic disparities. Appetite 117: 373-78. [CrossRef]

INE, Instituto Nacional de Estadística. 2018a. Encuesta de Población Activa, Módulo Conciliación entre la vida laboral y la familiar. Available online: https:/ / www.ine.es/dynt3/inebase/index.htm?type=pcaxis\&path=/t22/e308/meto_05/modulo/base_2011/2 018/\&file=pcaxis\&L=0 (accessed on 23 May 2021).

INE, Instituto Nacional de Estadística. 2018b. España en cifras. Available online: https:/ /www.ine.es/prodyser/espa_cifras/2018/2/ (accessed on 23 May 2021).

INE, Instituto Nacional de Estadística. 2021. Encuesta de Población Activa, serie 2009-2020. Available online: https: / /www.ine.es / jaxiT3/Datos.htm?t=10943\#!tabs-grafico (accessed on 23 May 2021).

Lambie-Mumford, Hannah. 2017. Hungry Britain: The Rise of Food Charity. Bristol: Policy Press.

Llano, Juan Carlos (coord.). 2019. El Estado de la Pobreza. $9^{\circ}$ Informe 2019. Madrid: EAPN España.

Llano, Juan Carlos (coord.). 2020. El Estado de la Pobreza. 10 Informe 2019. Madrid: EAPN España. 
Llobet, Marta, Paula Durán Monfort, Claudia Rocío Magaña González, Araceli Muñoz García, and Eugenia Piola Simioli. 2020. Précarisation alimentaire, résistances individuelles et expériences pratiques: Regards locaux, régionaux, transnationaux. Anthropology of Food 15. [CrossRef]

Lorey, Isabell. 2015. State of Insecurity: Government of the Precarious. Londres: Verso Books.

Ma, Christopher, Stephanie Ho, Siddharth Singh, and May Y. Choi. 2021. Gender Disparities in Food Security, Dietary Intake, and Nutritional Health in the United States. The American Journal of Gastroenterology 116: 584-92. [CrossRef]

Malgesini, Graciela, Silvina Monteros, Aurea Grané, and Rosario Romera. 2018. Valoración del impacto del Fondo de Ayuda Europea para las personas más desfavorecidas (FEAD) en España, a través de la percepción de las personas beneficiarias, Organizaciones y personal de gestión. Boletín Vulnerabilidad Social 16: 1-147.

Martín, José Moisés. 2019. Nueva Desigualdad en España y Nuevas Políticas para Afrontarla. Barcelona: Observatorio Social de La Caixa.

Martin, Molly A., and Adam M. Lippert. 2012. Feeding her children, but risking her health: The intersection of gender, household food insecurity, and obesity. Social Science Medicine 74: 1754-64. [CrossRef]

McIntosh, William Alex. 1996. World Hunger as a Social Problem. Edited by Donna Maurer and Jeffery Sobal. Eating Agendas. New York: Aldine de Gruytier.

Messer, Ellen. 2009. Rising Food Prices, Social Mobilization, and Violence: Conceptual Issues in Understanding and Responding to the Connections Linking Hunger and Conflict. In The Global Food Crisis: New Insights into an Age-Old Problem. Edited by David Himmelgreen. Memphis: NAPA Bulletin, vol. 32, pp. 12-22.

Mennell, Stephen. 1985. All Manners of Food. Eating and Taste in England and France from the Middle Ages to the Present. Londres: Basil Blackwell.

Neogy, Suniti. 2010. Gender Inequality, Mothers' Health, and Unequal Distribution of Food: Experience from a CARE Project in India. Gender and Development 18: 479-89. [CrossRef]

National Research Council. 2006. Food Insecurity and Hunger in the United States: An Assessment of the Measure. Washington, DC: The National Academies Press. [CrossRef]

Observatori d'Igualtat de Gènere. 2020. Les Dones a Catalunya 2020. Barcelona: Institut Català de les Dones.

O'Connell, Rebecca, and Julia Brannen. 2016. Food, Families and Work. London: Bloomsbury.

Offenhenden, María. 2017. 'Si hay que romperse, una se rompe'. El trabajo del hogar y la reproducción social estratificada. Ph.D. dissertation, Anthropology, Universitat Rovira i Virgili, Tarragona, Spain.

Patterson, Joanne G., Jennifer Russomanno, Andreas A. Teferra, and Jennifer M. Jabson Tree. 2020. Disparities in food insecurity at the intersection of race and sexual orientation: A population-based study of adult women in the United States. SSM Population Health 12: 1-11. [CrossRef]

Paugam, Serge. 2013. La Disqualification Sociale, Essai sur la Nouvelle Pauvreté. Paris: P.U.F.

Pearce, Diane. 1978. The Feminization of Poverty: Women, Work, and Welfare. Urban and Social Change Review 11: 1-2, $28-36,78$.

Pérez de Armiño, Karlos. 2018. Los bancos de alimentos en España durante la crisis: Su papel y discurso en un contexto de erosión de los Derechos sociales. In Derecho a una Alimentación Adecuada y Despilfarro Alimentario. Edited by Escajedo Leire, Esther Rebato and Alberto López Basaguren. València: Tirant lo Blanch, pp. 225-61.

Pfeiffer, Sabine, Tobias Ritter, and Elke Oestreicher. 2015. Food Insecurity in German households: Qualitative and Quantitative Data on Coping, Poverty Consumerism and Alimentary Participation. Social Policy and Society 14: 483-95. [CrossRef]

Pottier, Johan. 1999. The Anthropology of Food. Cambridge: Polity Press.

Prada-Trigo, José. 2018. Vulnerabilidad territorial, crisis y 'post-crisis económica': Trayectoria y persistencia a escala intraurbana. Scripta Nova 22: 1-23. [CrossRef]

Riches, Graham, and Tiina Silvasti. 2014. First World Hunger Revisited: Food Charity or the Right to Food. Londres: Palgrave Macmillan.

Russomanno, Jennifer, and Jennifer M. Jabson Tree. 2020. Food insecurity and food pantry use among transgender and gender nonconforming people in the Southeast United States. BMC Public Health 20: 1-11. [CrossRef]

Sachs, Carolyn, and Anouk Patel-Campillo. 2014. Feminist food justice: Crafting a new vision. Feminist Studies 40: 396-410.

Subirats, Marina. 2012. Barcelona: De la Necesidad a la Libertad. Las Clases Sociales en los Albores del Siglo XXI. Barcelona: UOC.

United Nations. 2015. The World's Women. Trends and Statistics. Nueva York: UN.

Valls, Francesc, and Angel Belzunegui. 2014. La Pobreza en España desde una Perspectiva de Género. Madrid: Fundación Foessa. Available online: http:/ / www.foessa2014.es/informe/uploaded/documentos_trabajo/15102014141447_8007.pdf (accessed on 4 July 2019).

Vasco Ramos Vasco, Mónica Truninger, Sónia Goulart Cardoso, and Fábio Rafael Augusto. 2020. Researching children's food practices in contexts of deprivation: Ethical and methodological challenges. International Journal of Qualitative Studies in Education.

Warde, Alan. 1997. Consumption, Food \& Taste: Culinary Antinomies and Commodity Culture. London: Sage Publications. 